\title{
The wealth gifted to the large-scale copper mining industry in Chile: new estimates, 2005-2014
}

\author{
Gino Sturla Zerene, Ramón E. López, Eugenio Figueroa B. \\ and Simón Accorsi O. ${ }^{1}$
}

\begin{abstract}
This article estimates the economic rents received by the 10 mines that comprise Chile's large-scale private-sector copper-mining industry. The methodology used produces a conservative calculation and includes two corrections that have hitherto been ignored in the literature: the reimbursement of exploration expenses and the compensation needed for volatility in the copper price. Estimates show that the wealth transferred to these firms between 2005 and 2014 was at least US\$114 billion. These rents are neutral in terms of investment and production decisions; in other words, if the private mining companies had paid the Chilean Treasury the calculated amount, their total investment and output would have been unchanged, but the country at large could have benefited from the huge voluminous resources in question. Moreover, in the absence of any other distortion, the firms would still have earned returns equivalent to what they would have obtained under perfect competition.
\end{abstract}

\section{Keywords}

Copper, mining, private sector, rent, measurement, natural resources, prices, tax revenues, Chile

\section{JEL classification}

Q30, Q32, Q33

\section{Authors}

Gino Sturla Zerene is a $\mathrm{PhD}$ candidate in Economics at the Department of Economics, Faculty of Economic and Business, University of Chile. Email: gsturla@fen.uchile.cl.

Ramón E. López is a full professor at the Department of Economics, Faculty of Economic and Business, University of Chile. Email: ramlopez@fen.uchile.cl.

Eugenio Figueroa B. is a full professor at the Department of Economics, Faculty of Economic and Business, University of Chile. Email: efiguero@fen.uchile.cl.

Simón Accorsi O. is a PhD student in Economics at the Department of Economics, Faculty of Economic and Business, University of Chile. Email: saccorsi@fen.uchile.cl.

\footnotetext{
The authors thank the following programmes and institutions: the National Doctoral Scholarship program of the National Commission for Scientific and Technological Research (CONICYT), for support provided to Gino Sturla Zerene; the Department of Economics of the Faculty of Economics and Business (FEN) of the University of Chile, for the scholarship supporting Simón Accorsi O. and Gino Sturla Zerene; and the FEN Centre for the Economy of Natural Resources and the Environment (CENRE), for support provided to the research project "Economic Rents from Chile's Natural Resources", of which this study forms part.
} 


\section{Introduction}

"... all Chileans need to consider how an additional peso can be put to best use - an extra peso for a bridge, a school, a public-sector worker, a pensioner..."

Rodrigo Valdés, Minister of Finance of Chile, 2015-2017, La Tercera newspaper, 25 August 2016, Santiago.

"...we must not let this vast and wealthy region become nothing more than a foreign factory..."

José Manuel Balmaceda, President of Chile, 1886-1891, Message to Congress, 1 June 1889, Santiago.

Chile's large-scale private-sector copper-mining industry consists basically of 10 large transnational corporations which account for around 60\% of all copper produced in the country. Most of the copper produced by these firms is exported as concentrate, which implies a minimum level of product processing. In addition to the large private-sector mines, there is a public-sector firm, Corporación Nacional del Cobre de Chile (CODELCO), which generates about one third of Chile's total copper production.

Copper is responsible for a huge share of Chile's tax revenues; yet the bulk of copper's contribution to the Chilean State comes from CODELCO (around 60\% of the total), while the 10 large private-sector mining firms contribute less than half of that amount. In other words, CODELCO's effective tax rate per ton of copper produced is nearly four times higher than the rate faced by the large private-sector mining companies.

This provides a major justification for this study: why do large private firms pay much lower taxes than the State enterprise - especially when CODELCO's mines are much older and have a far lower average mineral grade?

Nonetheless, CODELCO's heavy tax burden has not prevented it from maintaining a healthy financial situation in most years. This implies that the private mining firms could contribute much more to the Chilean State than they currently pay, without jeopardizing their economic viability; and they would still earn normal rates of return on their capital.

In other words, it would appear that private mining companies are appropriating large economic rents. This paper attempts to put a value on those rents, using very conservative assumptions in its estimation, in order to provide a lower-bound value.

The article is organized as follows. Section II sets out the conceptual framework to be used, emphasizing the concept of economic rent and its relationship to natural resources and the mining rent. It also makes a brief review of the literature on this subject in the case of Chile. Section III describes the process by which mining rents are estimated by the World Bank, which also provides the data set used in this study. Section IV describes the methodology used to calculate the rents, and section V presents the results. The article concludes with some final thoughts.

\section{Conceptual framework}

\section{Economic rent}

The classic definition of economic rent refers to the excess economic return that a specific factor of production receives - that is, an amount above the minimum return needed for it to continue in the same use. When all factors of production are considered together, the economic rent associated 
with a productive enterprise can be understood as a payment above the minimum necessary for the enterprise to remain in a given economic activity. The origin and subsequent theoretical development of this concept are discussed in the Letters of David Ricardo, 1810-1815, compiled by Piero Sraffa (Ricardo, 2005), in the literature review by Tollison (1982), and in the studies of Shepherd (1970) and Hammes (1985), among other sources.

In the concept of economic rent, the opportunity cost of all productive resources used is already discounted. Since opportunity costs include the profit that would have been made if the resources employed in a certain activity had been invested in the next best alternative use, economic rent represents a surplus over the profit needed to allocate the resources to the activity in question. More simply, the rent is the surplus value of production after deducting all costs, including a normal return on capital and relevant risk premiums. Wessel (1967) distinguishes between the concepts of Ricardian and Paretian rent, emphasizing that the latter is calculated by deducting opportunity costs. The present study uses the concept of economic rent in its Paretian sense.

\section{Economic rent and natural resources}

A key feature of natural-resource-based economies is that they tend to generate large economic rents, which can inflate the return earned on the capital that exploits them to levels well above normal rates of return. The economic rent generated by the activities in which the natural resources, whether renewable or non-renewable, are extracted, directly constitutes the in situ scarcity value of the resources in question. Hence, the rent is what the owner of the natural resource can legitimately charge entities that use the resource in a productive process. The present study focuses on the calculation of this rent in Chile, specifically, the rent received by the 10 firms that form the large-scale private-sector copper-mining industry (gran minería privada del cobre), hereinafter referred to as GMP-10.

\section{Origin of economic rent in the mining industry}

Minerals differ from other natural resources, since they require an "exploration" phase prior to extraction or exploitation. Finding minerals has been a historically difficult and expensive task, with slim chances of success. There are two different mineral exploration regimes:

(i) Free-entry exploration: in this mode of operation, there is perfect competition in the exploration market, so the rents accruing to the economic agents that undertake exploration work tend to dissipate in the long run.

(ii) Exploration subject to entry barriers: this situation can involve lobbying mechanisms that impede free access to exclusive exploration concessions, or simply the maintenance and exploitation of the rights derived from concessions previously granted by the State. In both cases, the final de facto effect is the existence of entry barriers to exploration, which also then become de facto entry barriers to the extraction or exploitation of the mineral in question. This situation generates an institutionally-based artificial shortage; and it constitutes a source of rent appropriation by the mineral exploration and extraction firms. Moreover, the rent generated under this regime does not dissipate as it does under free entry: firms that enjoy exclusive access to mineral deposits tend to appropriate these rents; and, given the heterogeneity of the deposits and the natural scarcity of the mineral resource, the existence of these rents does not elicit additional investment. This is because the return on capital obtained from mines currently being operated can seldom be replicated, since the costs of exploring and exploiting new potential deposits are usually greater than those of deposits already discovered and in operation. 
This study considers the second of the two regimes, since Chile has legislation that grants exclusive exploration concessions and mining rights, on a cost-free basis and in perpetuity. In 2013, $42 \%$ of the country's total area was under concession, encompassing all zones with mining potential (SERNAGEOMIN, 2013). In Chile, therefore, copper is a resource for which the scarcity value is determined by entry barriers to exploration activities, which grant free and exclusive access to a handful of firms. In the case of GMP-10, the firms in question own the exploration and exploitation concession, which enables them to retain the corresponding rents.

\section{The nomenclature used in the study}

- WB total mining rent: the rent calculated by the World Bank in relation to all the mining activity undertaken in Chile. The estimated amounts can be found in World Bank (2016).

- WB GMP-10 mining rent: that portion of the WB total mining rent associated with the companies that operate the 10 mines that comprise the large-scale private-sector copper-mining industry in Chile.

- GMP-10 compensated rent: the remaining rent, obtained by taking the WB GMP-10 mining rent (in which all production costs have already been deducted from the value of mineral sales) and subtracting two additional compensatory returns that have not previously been considered in any study on Chile. These are:

(i) the return needed to compensate for the high risk associated with mineral exploration activity; and

(ii) the return needed to compensate for the high risk associated with the volatility of the price of the raw materials (copper) on the international market.

- GMP-10 appropriated gratuitous rent: this is obtained by subtracting the GMP-10 compensated rent from the tax revenue that the State of Chile obtained from the large-scale private-sector copper-mining industry. This corresponds to economic rent as strictly defined; so, if it were taxed away, it would not generate distortions in the economy. This rent is referred to as "gratuitous" because it should pertain to the owner of the mineral ore (the State of Chile), but instead is gifted to the firms that exploit it.

\section{Studies of mining rent in Chile}

Despite the fundamental importance of mining rents for Chile's economy, few studies exist on the subject. The most important is undoubtedly that done by the World Bank (2011), which is described in greater detail in section III.

Although mining rents have been estimated in recent years, the studies in question contain major methodological errors. For example, when calculating the economic rent, Poblete (2015) considers the sales that the mining firms report rather than the total production of copper and other minerals at market price. This is not consistent with economic theory and generates a serious distortion, since a large proportion of sales is reported at transfer prices, which are generally below the market price (COCHILCO, 2015; Correa, 2016).

None of the recent studies considers exploration expenses, which must be increased ex-ante, since exploration activity entails a high probability of failure which must be economically compensated. A second issue that is ignored is compensation for the volatility of copper prices, which requires the rents to valued at trend prices rather than at the prices observed on the market. Failure to do so may result in rents being overestimated when measured in a mineral price upswing or supercycle period. 


\section{A modern methodology}

The methodology used in this study ensures that the rents estimated correspond to a "lower bound" or minimum value. For that purpose, two important corrections are made which are generally ignored in the literature - even in the estimates by the World Bank and the Organization for Economic Cooperation and Development (OECD) - which significantly reduce the estimated amount of the rent:

(i) Exploration expenses: to maintain their long-term production potential, copper mining firms must undertake a lot of exploration work to replace deposits that are becoming depleted. The fact that mineral exploration activities are often unsuccessful means they are subject to a high risk that needs to be rewarded with a higher ex ante rate of return. Thus, when calculating the economic rent, apart from deducting observed exploration costs, the calculation must also include a premium for the ex ante risks of these expenses.

(ii) Commodity-price volatility: the prices of raw materials, particularly copper, fluctuate widely, with periods of very low prices and other high-price or boom periods. As a result, rents that may seem excessive during peak periods may, in part, be merely compensating for losses occurring during low-price phases. Measuring rents in periods of very high prices, as at the time of this study, can lead to overestimation; so taxing them away completely would be distorting. This problem is tackled by removing the effect of short-term fluctuations from the copper price and using trend prices instead of those observed in the market. The values thus estimated correspond to long-term rents.

This methodology involves estimating a minimum value of the rent compared to more conventional measures. This can be a disadvantage, since the true value of economic rent tends to be underestimated. Nonetheless, the study aims precisely to estimate the rent as conservatively as possible, to obtain a lowerbound value. From the public-policy standpoint, the risk involved in not taxing all of the rent is likely to have less negative consequences than to tax it in excess as a result of overestimates. In the first case, an underestimation of the rent only causes a distributive effect because less revenue is collected than could otherwise be obtained. In the second case, if the rent is overestimated, taxing it can cause economic-efficiency losses.

The methodological procedure used in this study is as follows. The World Bank measurement of Chile's total mining rent is used to obtain the GMP-10 portion, which is implicit in the WB calculation and amounts to US $\$ 204$ billion in 2005-2014. ${ }^{2}$ This is then reduced by deducting the amounts needed to offset the uncertainty of exploration expenditure (just over US\$ 18 billion) and to compensate for the volatility of the copper price (nearly US\$30 billion). The GMP-10 compensated rent is thus calculated as US\$ 156 billion. From this amount, the taxes paid by GPM-10 (nearly US\$ 42 billion) are deducted to obtain a GMP-10 gratuitous rent of US\$114 billion. This amount is equivalent to almost six times the total value of Chile's current sovereign wealth funds (Ministry of Finance, 2015).

\section{Mining rents according to the World Bank}

\section{General considerations}

In the study The Changing Wealth of Nations: Measuring Sustainable Development in the New Millennium (World Bank, 2011), the World Bank calculated the mining rents of various countries, including Chile; and these have now been updated to 2014. This official database spans a 45-year period and is kept permanently up to date.

The calculation methodology (World Bank, 2011, Brandt, Schreyer and Zipperer, 2013) considers the following:

2 This article uses United States dollars at October 2016 prices throughout. 
- The production of minerals, measured in terms of refined units equivalent, associated with the deposits or mines located in the country.

- $\quad$ The price observed on the international minerals market, for the purpose of estimating sales value, which generally differs from the amount reported by the companies themselves.

- The total costs of mining production in deposits or mines, including the opportunity cost of capital (Brandt, Schreyer and Zipperer, 2013).

In the case of Chile, this study considers the following mining products in addition to copper: tin, gold, lead, zinc, iron, nickel, silver, bauxite and phosphate. Copper rents are predominant - accounting for over 95\% - compared to the rents associated with other minerals, especially in 2005-2014 (Brandt, Schreyer and Zipperer, 2013). Moreover, most of the minerals considered are themselves by-products of the large-scale copper mining industry and are therefore present, although to a lesser extent, in these firms' revenues. It should be noted that the contribution made by these minerals to the calculated rents is underestimated, since the by-products of the large private copper mining sector have been systematically under-reported owing to the lack of measurements by laboratories that are genuinely independent of the mining companies (Castillo, 2015).

It should be noted that the rents measured by the World Bank do not correspond to economic rents strictly defined - as used in this study - since they do not deduct the returns needed to compensate for exploration expenditure risks and the volatility of international mineral prices. These two issues are addressed in this study and the corresponding calculations are made.

\section{Mining rents in Chile compared to those of other copper-producing countries}

In 2014, 31\% of all copper produced in the world was mined in Chile, as shown in figure 1 which reports the global production shares of the 10 countries that extracted the largest amount of copper in that year.

Figure 1

Share of the largest copper-producing countries in global copper production, 2014 (Percentages)

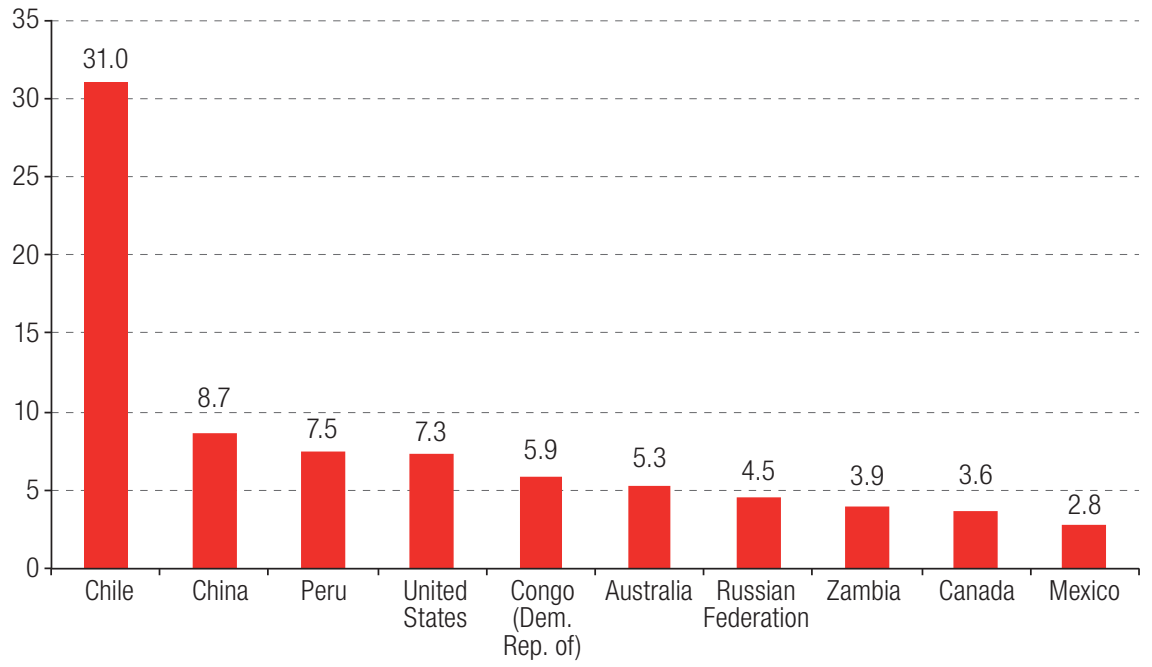

Source: Prepared by the authors, on the basis of World Bank, World Development Indicators, 2016.

Figure 2 displays mining rents from 1970 to 2014, as calculated by the World Bank (World Bank, 2016) in the six countries that produced the most copper in the latter year. Rents are expressed as a proportion of gross domestic product (GDP). This figure shows that, in Chile, mining revenues 
exceeded 5\% of GDP nearly every year, even in periods when the price of copper was very low. This suggests that the generation of economic rents is not merely a cyclical phenomenon, typical of periods of prosperity in the copper market, but clearly a long-term issue.

Figure 2

Annual mining rent as a percentage of GDP in the six countries that produced the most copper in 2014, 1970-2014

(Percentages)

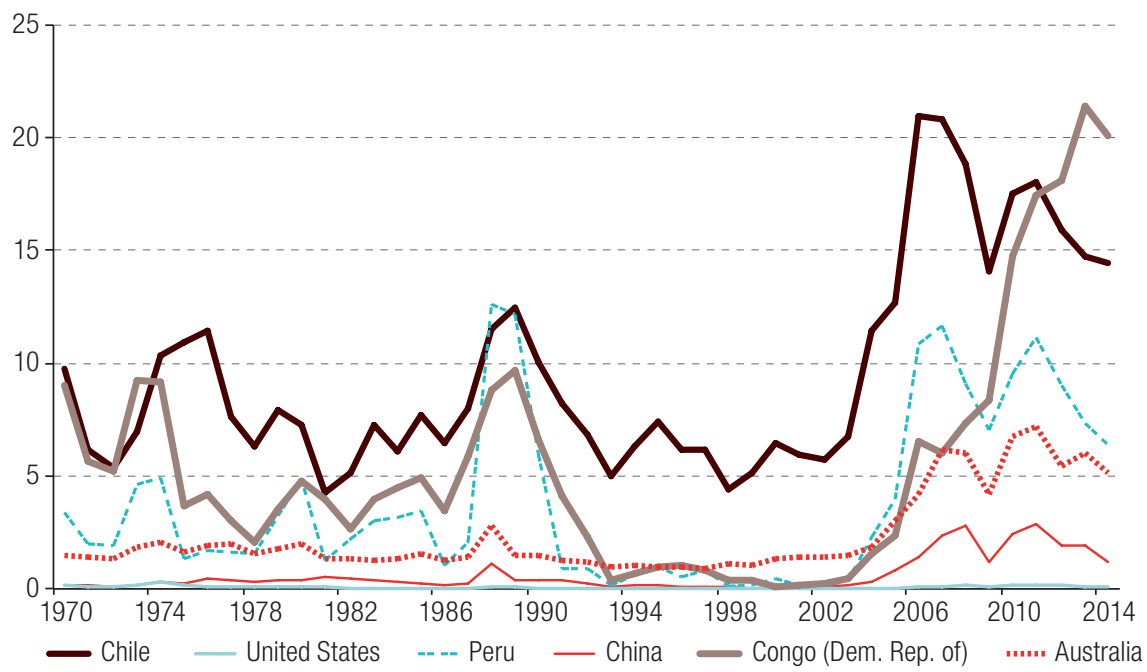

Source: Prepared by the authors, on the basis of World Bank, "World Development Indicators", 2016.

a GDP means gross domestic product.

\section{Mining rents in Chile as estimated by the World Bank}

Figure 3 shows the value of mining rents in 2005-2014, as estimated by the World Bank for Chile (World Bank, 2016), totalling US\$ 389 billion, with an annual average of US\$ 38.9 billion, representing $17 \%$ of Chile's GDP.

Figure 3

Chile: annual economic rent from mining, as estimated by the World Bank, 2005-2014

(Billions of dollars) $^{\text {a }}$

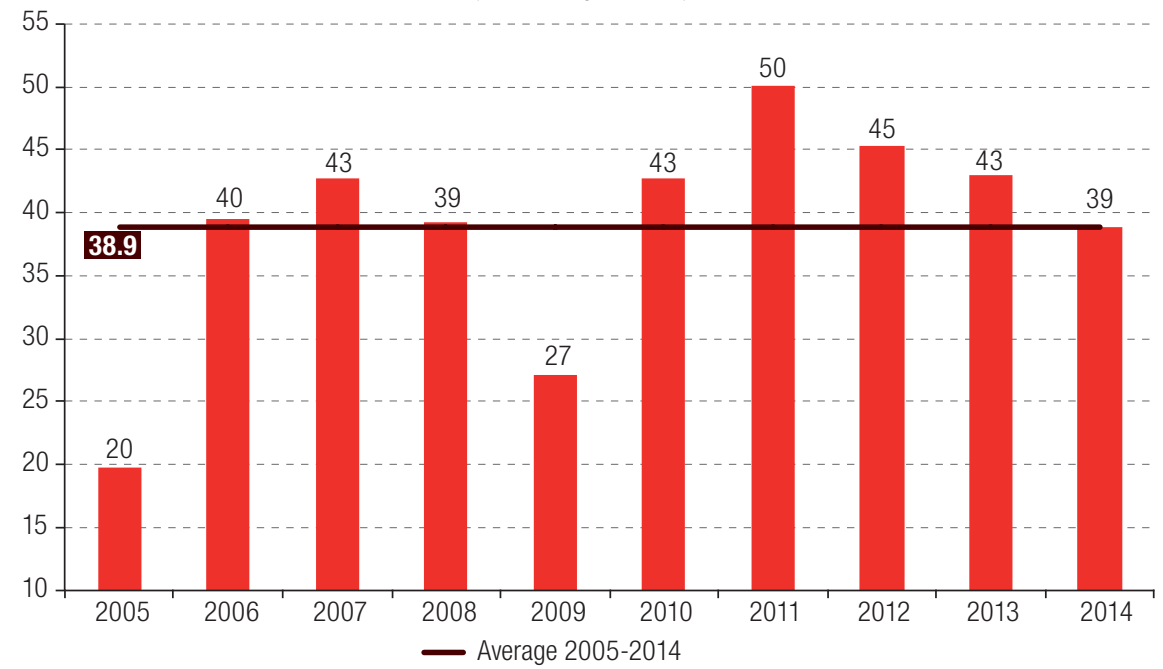

Source: Prepared by the authors, on the basis of World Bank, "World Development Indicators", 2016.

a At October 2016 prices. 


\section{Methodology for calculating the GMP-10 appropriated gratuitous rent}

\section{General considerations}

Between 2005 and 2014, GMP-10 has accounted for an average of 57\% of Chile's copper production; and when CODELCO is included, the figure rises to $88 \%$. The remaining $12 \%$ is produced by smaller mines. Although there are deposits, such as Spence, El Tesoro and Esperanza, which have outputs similar to those of the GMP-10 firms, these are not yet officially listed in this group (COCHILCO, 2015). That is the first reason why these deposits have not been included in this study; the second reason is that two of them only started operating after 2005.

The aim is to estimate the appropriated GMP-10 gratuitous rent in an economically consistent way. This is done in four stages, based on the amounts of total mining rent reported by the World Bank:

(i) determination of WB mining rent (CODELCO + GMP-10)

(ii) calculation of WB GMP-10 mining rent

(iii) estimation of GMP-10 compensated rent

(iv) calculation of GMP-10 appropriated gratuitous rent

This section develops the methodology for the first three of these stages. The last stage merely involves deducting the taxes paid by GMP-10 to the State of Chile from the GMP-10 compensated rent obtained in stage 3.

\section{Calculation methodology}

The mining rent measured by the World Bank in relation to Chile (World Bank, 2016) corresponds to the total rent generated by the mining sector of the Chilean economy, for which a methodology has been established to obtain the WB GMP-10 mining rent and subsequently the GMP-10 compensated rent. The calculation methodology used is described in this section. A basic element of the methodology is that the value of mineral sales is measured on the basis of the international prices of the metal rather than the sales reported by the firms, as has been done in other studies. This approach follows the method implemented by the World Bank (2011) and by Brandt, Schreyer and Zipperer (2013); and it has the advantage of being independent of company reports, which often understate sales in order to reduce taxes.

\section{(a) CODELCO plus GMP-10}

The rent estimated by the World Bank in relation to CODELCO and GMP-10 is assumed equivalent to their share in Chile's total copper production each year. This method of obtaining the rent associated with the large-scale copper mining industry (public and private) is consistent and conservative. Brandt, Schreyer and Zipperer (2013) show that the mining rents associated with the large-scale copper mining industry account for $90 \%$ of the rent generated by all natural capital recorded in Chile. Data from the World Bank (2016) show that in 2005-2014, 89\% of the country's natural-resource rents came from mining. To obtain the rent from large-scale mining, the rent obtained from medium- and small-scale copper mining should be excluded from this total amount. Accordingly, based on the two studies mentioned above, the following methodological criterion has been defined: each year, the proportion of the mining rent reported by the World Bank, corresponding to the large-scale copper mining industry 
(both public and private) will be equivalent to the latter's share in total copper production in Chile. This is a conservative assumption, since rents obtained from large-scale mining tend to be higher than those of small and medium-sized mines, as a proportion of their production.

The mining rent calculated by the World Bank for GMP-10 $\left(R_{b m, G m p 10}\right)$ and the State-owned CODELCO $\left(R_{b m, C o d}\right)$ can be expressed as:

where

$$
R_{b m, G m p 10}+R_{b m, C o d}=(1-B) \cdot R_{b m, T o t a l}
$$

$B=$ the share of total World Bank mining rent that does not correspond to GMP-10 or to CODELCO, and $R_{b m, \text { Total }}=$ total World Bank mining rent.

\section{(b) WB GMP-10 mining rent}

The same World Bank procedure (Brandt, Schreyer and Zipperer, 2013) can be used to express the WB GMP-10 mining rent in terms of the WB CODELCO rent, from equation (1), as follows:

$$
R_{b m, C o d}=p \cdot q_{C o d}+S_{C o d}-c_{C o d} \cdot q_{C o d}-(r+\delta) \cdot K_{C o d}
$$

where,

$p=$ market price of copper,

$q_{\text {Cod }}=$ CODELCO production,

$S_{C o d}=$ additional revenue from CODELCO by products,

$c_{C o d}=$ total unit cost of CODELCO operations, ${ }^{3}$

$r=$ normal rate of return to capital,

$\delta=$ capital depreciation rate, and

$K_{\text {Cod }}=$ CODELCO capital stock.

Thus, it is possible to obtain the following expression for the World Bank GMP-10 mining rent.

$$
R_{b m, G m p 10}=(1-B) \cdot R_{b m, T o t a l}-R_{b m, C o d}
$$

\section{(c) GMP-10 compensated rent}

The GMP-10 compensated rent $\left(R_{C, G m p 10}\right)$ is the World Bank rent corresponding to GMP-10, with two additional corrections: exploration risk premium $(\eta)$ and compensation for the volatility of the copper price $(\phi)$.

$$
R_{C, G m p 10}=R_{b m, G m p 10}-\eta-\phi
$$

The exploration risk premium for GMP-10 $(\eta)$ is defined on the basis of López and Figueroa (2014). This premium corresponds to the increase in exploration expenditure, according to the probability of success in the exploration tasks, and the rate of return to capital, less the declared exploration expenditure:

$$
\eta=E_{G m p 10}\left[\frac{r}{1-\theta}-1\right)
$$

\footnotetext{
3 This total operating cost does not correspond to the direct unit operating cost, c1, referred to below, because corrections have been made to take account of copper sold in concentrate form. Annex A1 describes the methodology used to take account of the fact that CODELCO sold an average of $14 \%$ of its copper in unrefined state during the period.
} 
where

$E_{\text {Gmp } 10}=\mathrm{GMP}-10$ exploration expenditure

$(1-\theta)=$ probability of success in GMP-10 exploration tasks

The compensation for volatility in the copper price $(\phi)$ is defined from the difference between the market price and the copper trend price (detail in section IV.3.c).

$$
\phi=\left(p-p_{T}\right) \cdot q_{G m p 10}
$$

where,

$p_{T}=$ trend price of copper

$q_{\text {Gmp } 10}=$ GMP-10 copper production

Thus, (4), (5) and (6) give equation (7), in which the GMP-10 compensated rent is expressed in terms of the WB GMP-10 mining rent and additional corrections.

$$
R_{C, G m p 10}=R_{b m, G m p 10}-E_{G m p 10}\left[\frac{r}{1-\theta}-1\right]-\left(p-p_{T}\right) \cdot q_{G m p 10}
$$

\section{Data for the calculation}

\section{(a) General information}

To make the required estimates, annual data are needed on the international price of copper and on the total costs and production of GMP-10 and CODELCO. Costs and production levels (copper and by-products) have been obtained from the Chilean Copper Commission (COCHILCO, 2015). The average cost per unit among GMP-10 is US\$ 1.60 per pound and that of CODELCO is US\$1.29 per pound (FCH/Alta Ley/CORFO, 2015). This indicates that the State firm is more efficient, so it will generate higher rents. To calculate the annual economic rent of GMP-10, these production costs may be biased towards understatement, since studies by international consultants indicate that CODELCO's production cost is higher than that GMP-10 (Mining Press, 2013). On the other hand, the average annual production of GMP-10 was 3,070,000 tons of refined copper per year, while that of CODELCO was 1,756,000. The capital stock, of both CODELCO and GMP-10, has been calculated on the basis of the perpetual inventory system formula.

It is also assumed that the normal rate of return on capital required by investors in Chile is $10 \%$. This could also understate the annual GMP-10 rent, however, since it is higher than the normal rate that Brandt, Schreyer and Zipperer (2013) estimate and use in relation to Chile. In fact, some major mining projects use $8 \%$ rates of return to gauge the feasibility of investment projects in Chile. An example is the Alto Maipo Hydroelectric Project, whose shareholders expected an 8\% return on their investment of over US\$ 2 billion. ${ }^{4}$ The shareholders were AES Gener and Antofagasta Minerals, the latter being the owner of the Los Pelambres mining company, which is one of the GMP-10 firms.

To calculate untaxed rent, the tax base permitted by the mining legislation is used, including deductions for all variable costs plus financial costs. In addition, capital assets can be depreciated at an accelerated rate, which can be as little as three years in the case of machinery and equipment.

\footnotetext{
4 This information was obtained recently from the Chilean newspaper El Mercurio (2017), in the context of the near-final decision not to build the hydroelectric power station and the "legitimate return" claimed by its shareholders.
} 


\section{(b) Return on exploration expenditure}

To correct for the return on capital that is required in exploration activities, the WB GMP-10 mining rent must be reduced by the exploration expenses that private mining companies are forced to incur to sustain their activity over time. This expense is considered ex-ante, in other words the expected returns must include the probability of succeeding or failing in the exploration activities, in the planning stage. As noted by López and Figueroa (2014), companies should be allowed to legitimately appropriate part of the profits or mining rent, in order to undertake mining exploration activities. The portion in question must be calculated on the basis of the expected profitability of the exploration performed, including the probability of success of the activity.

Bartrop and Guj (2009) define a typology of mining exploration activities. To avoid the economic rent being overestimated; and, following these two authors, Chile's GMP-10 has been typified as an industry that has carried out and permanently undertakes exploration work in search of large deposits in unexplored areas. It is also considered that exploration faces a high level of risk because there is little previous work, the geology is poorly known, the explorable areas are remote, and large-scale exploration programmes are required. The lowest value of the probability of success is $2.5 \%$, which could be considered excessively low for Chile, given current knowledge of the geology of certain areas and the amount of copper thought to exist in the subsoil of certain areas of the country, for example. Nonetheless, this assumption makes it possible to maintain conceptual consistency and avoid the risk of overestimation when calculating the net GMP-10 rent. In view of the above, the premium, ex ante, turns exploration expenditure into an investment needed to sustain the mining activity.

Figure 4 reports the annual exploration expenditure of all private mining firms in Chile, which here are assumed to be equivalent to GMP-10, according to the data provided by COCHILCO (2015). It also displays the premium for exploration expenditure, which in the case of this study corresponds to three times the declared expenditure, given a 10\% normal rate of return and a $2.5 \%$ probability of success.

Figure 4

Chile: annual GMP-10 exploration expenditure and the compensatory return required by this activity, 2005-2014

(Billions of dollars) ${ }^{2}$

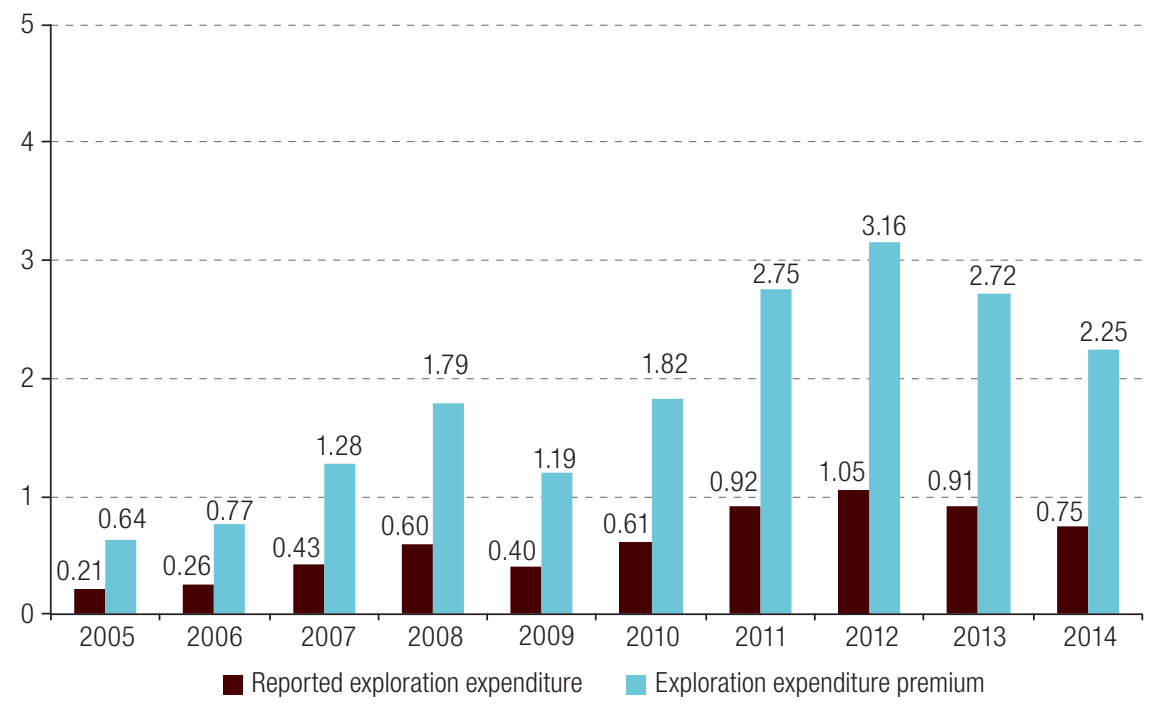

Source: Prepared by the author, on the basis of COCHILCO (Chilean Copper Commission), Anuario de estadísticas del cobre y otros minerales, 1996-2015, Santiago, 2015.

a At October 2016 prices. 
This way of measuring exploration expenses has the potential for overestimation, especially since the data used to calculate them comes from what the firms themselves declare; and the firms have incentives to inflate them artificially. Unfortunately, this is the only available source of data on exploration expenses.

\section{(c) Return for copper price volatility}

The price of copper has fluctuated widely over the last 45 years, including a strong upswing at the start of the twenty-first century. This section uses a 45-year series of copper prices spanning 1970-2014, together with time series tools, to determine a long-term or trend price for copper in 2005-2014. The aim is to recalculate the GMP-10 mining rent, using a long-term copper price series, from which the cyclical component has been removed. In other words, the copper prices observed each year are turned into a smoothed long-term trend series, from which short-term fluctuations have been eliminated.

There are several tools available to decompose trend cycles, of which the most basic is linear regression. The time-series literature provides sophisticated statistical methodologies that have computer packages that can be applied to observed time series. The most widely used and validated methodology is probably the HP filter (Hodrick and Prescott, 1997). The present study uses the HP-100 filter, which is recommended for the annual series, to extract a trend price from the observed series. The HP-100 filter makes it possible to decompose the observed price series into a cyclical component and a trend component. Thus, the trend series of the price can be interpreted as the time sequence of the longterm price. Figure 5 shows the evolution of the observed copper price with a solid black line and the long-term trend price with a dashed grey line.

Figure 5

International observed copper price and long-term price obtained using the Hodrick and Prescott filter, 1970-2015

(Dollars per pound) ${ }^{\mathrm{a}}$

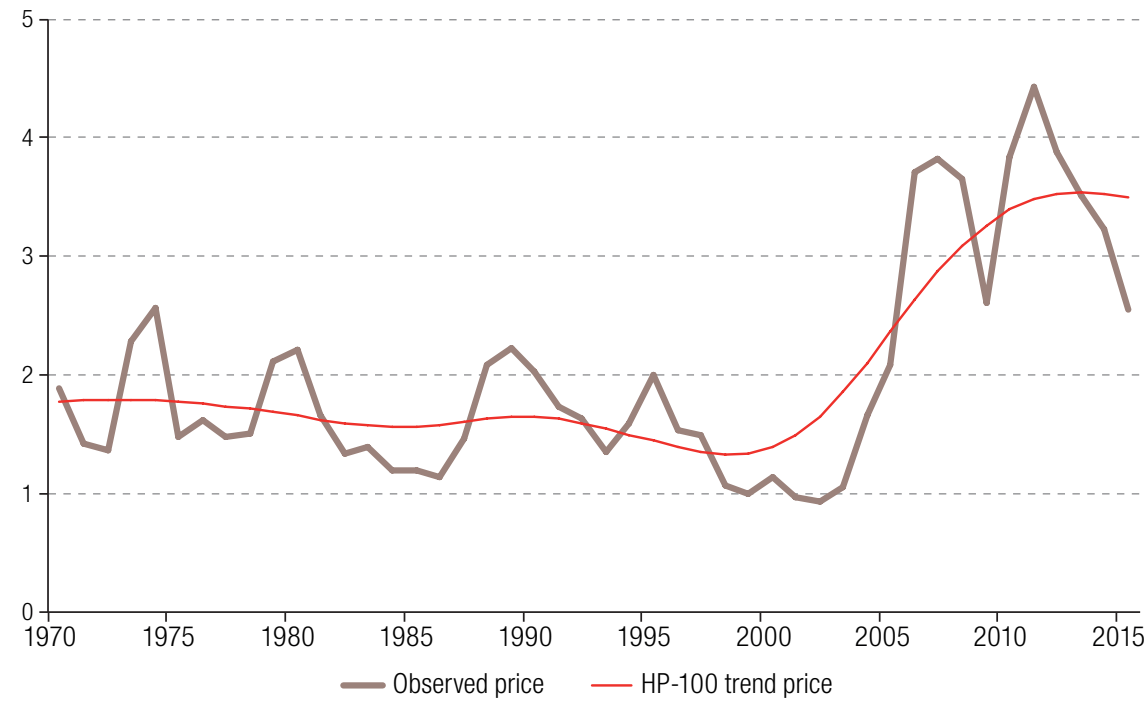

Source: Prepared by the authors.

a At October 2016 prices. 
The WB GMP-10 mining rent is recalculated on the basis of the trend copper price in 2005-2014. The costs -including opportunity costs - are exactly the same as before; the only variable that changes is the copper price. ${ }^{5}$

\section{Results}

\section{GMP-10 compensated rent}

This section presents the GMP-10 compensated rent, which is estimated by subtracting, from the WB GMP-10 mining rent, both the premium for the risk involved in mining exploration activities and the compensation required for the volatility of the copper price. Figure 6 displays the GMP-10 compensated rent estimated in this way. The adjustment reduces the GPM-10 rent by US\$29.7 billion in 2005-2014, simply because the prices observed during this period are above trend. In addition, the correction for the deduction of the exploration risk premium reduces the estimated GMP-10 rent by another US\$ 18.6 billion in the period considered. Thus, when incorporating both corrections, the estimate of GMP-10 compensated rent is US\$ 48.3 billion lower than that of the World Bank in the period as a whole. In other words, the WB GPM-10 mining rent in the period is reduced from US\$ 204 billion to about US\$156 billion. This means that the average annual rent for 2005-2014, corrected after deducting both components, amounts to US\$15.6 billion, which corresponds to $6.9 \%$ of Chile's GDP. This amount is US\$ 4.8 billion less than the WB GMP-10 mining rent.

Figure 6

Chile: annual GMP-10 compensated rent, 2005-2014

(Billions of dollars) $^{\text {a }}$

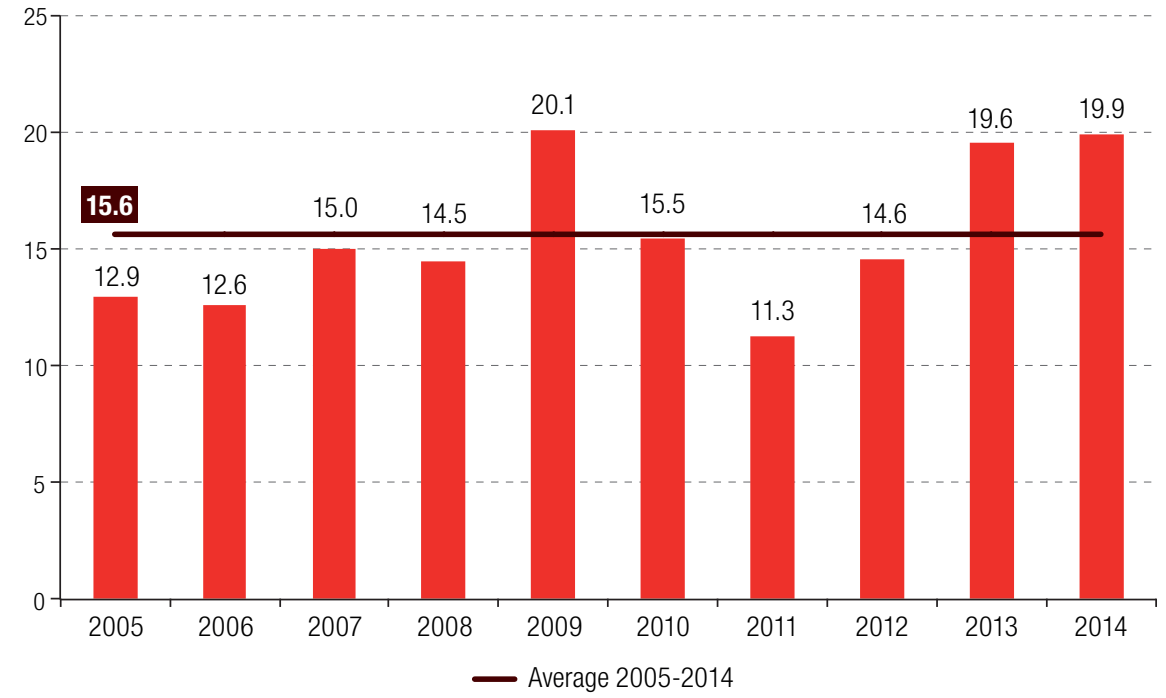

Source: Prepared by the authors.

a At October 2016 prices.

\footnotetext{
5 The mining companies' net profitability for 2017 was calculated using the methodology described in this study based on trend copper prices. The trend price for 2017 turns out to be US $\$ 2.82$ per pound of copper, slightly higher than the price reported by the Mining Council (US\$2.70 per pound) but very similar to that predicted by Goldman Sachs (US\$2.85 per pound). This projection yields an average net pre-tax rate return on capital of nearly $40 \%$ in this year for the 10 large private mining companies - equivalent to about US\$ 9 billion.
} 


\section{GMP-10 appropriated gratuitous rent}

Section II.4 defined the GMP-10 appropriated gratuitous rent as GMP-10 compensated rent minus the taxes paid by the large-scale private mining sector in each year of the period studied. These taxes, as defined in the Chilean tax code, are of three types: (i) first category tax, which is levied on the firms' taxable profits; (ii) additional tax, which taxes Chilean-source earnings by natural or legal persons without domicile or residence in Chile; and (iii) the specific mining duty (IEM), which taxes mining activity profits obtained by a mine operator. Figure 7 shows the tax revenue received from GMP-10 by the Chilean Treasury (DIPRES, 2015), which totalled US\$ 41.6 billion in 2005-2014.

Figure 7

Chile: tax revenue obtained from GMP-10 by the Chilean Treasury, 2005-2014 (Billions of dollars) $^{\mathrm{a}}$

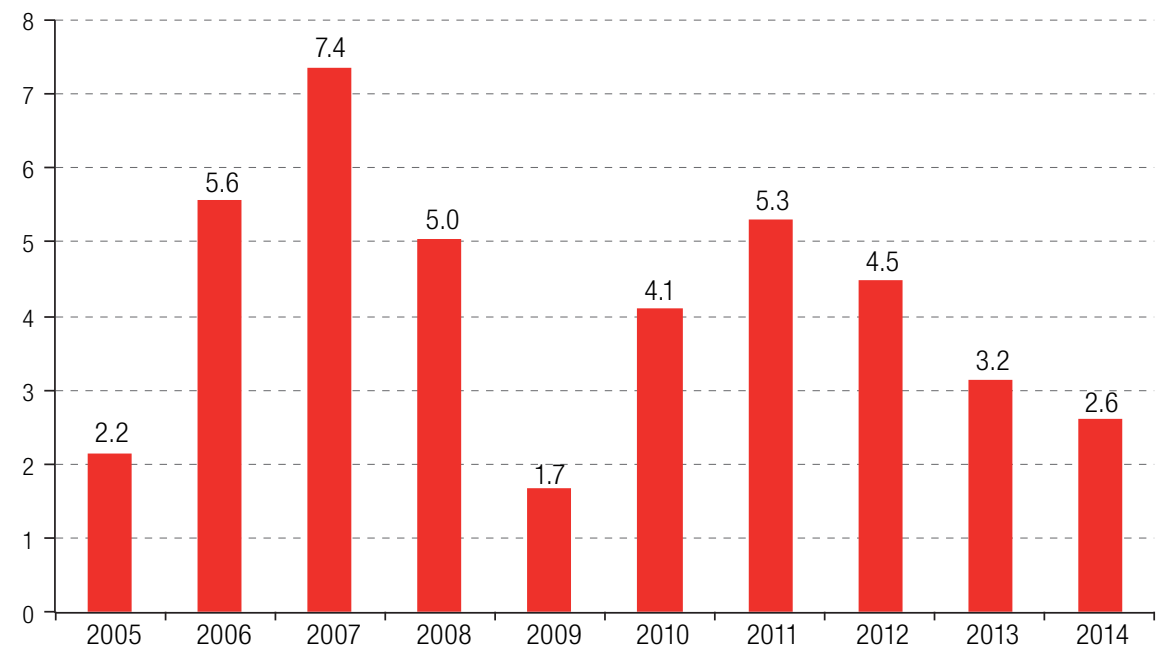

Source:Prepared by the authors, on the basis of Budgetary Affairs Bureau, "Evolución, administración e impacto fiscal de los ingresos del cobre en Chile", Santiago, Ministry of Finance, 2015 [online] http://www.dipres.gob.cl/572/articles133158_doc_pdf.pdf.

a At October 2016 prices.

Subtracting taxes paid from the GMP-10 compensated rent gives the GMP-10 appropriated gratuitous rent, amounting to US\$ 114 billion in the study period. This amount represents an average of US\$11.400 billion per year, equivalent to $5.1 \%$ of GDP and $23.3 \%$ of public spending during the period. Figure 8 shows the GMP-10 appropriated gratuitous rent, in dollars at October 2016 prices (annex A2 contains figures displaying this rent relative to GDP and as a percentage of public expenditure). 
Figure 8

Chile: GMP-10 appropriated gratuitous rent per year, 2005-2014

(Billions of dollars) ${ }^{a}$

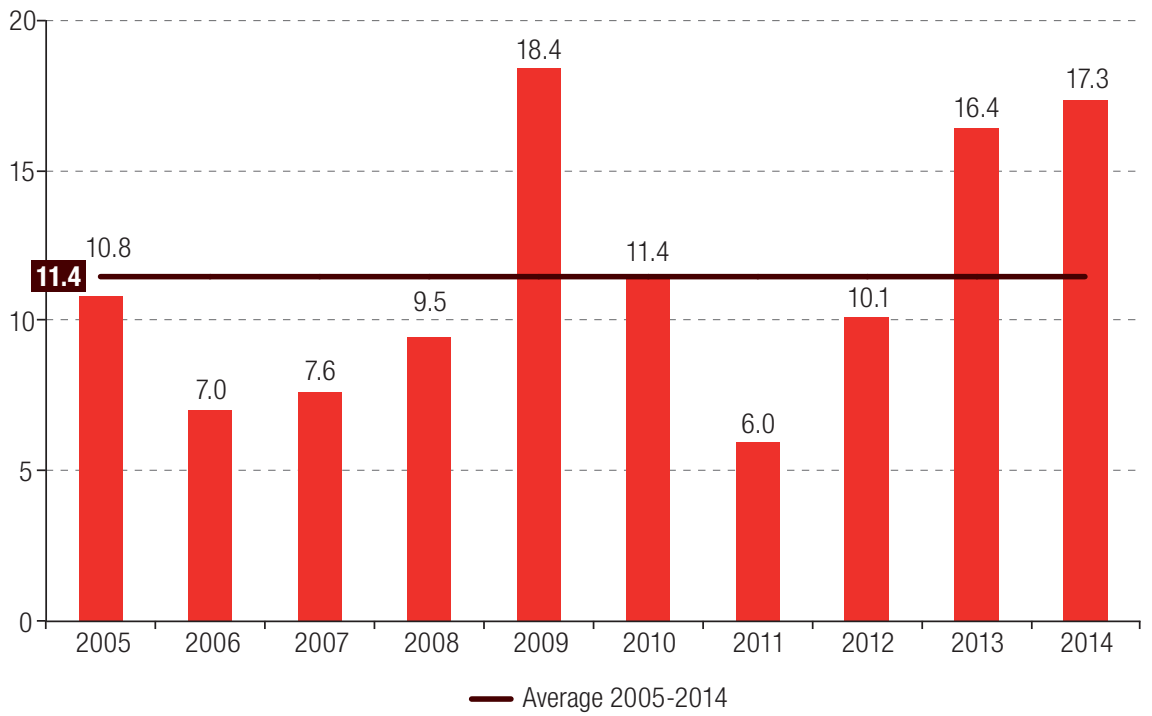

Source: Prepared by the authors.

a At October 2016 prices.

\section{Summary of results}

Figure 9 displays the total amounts of each of the four economic rents defined in this paper, in the period spanning 2005 to 2014. The amounts are expressed in millions of dollars at October 2016 prices (the time trend is shown in annex A3).

Figure 9

Chile: mining rents by type, 2005-2014

(Millions of dollars) $^{a}$

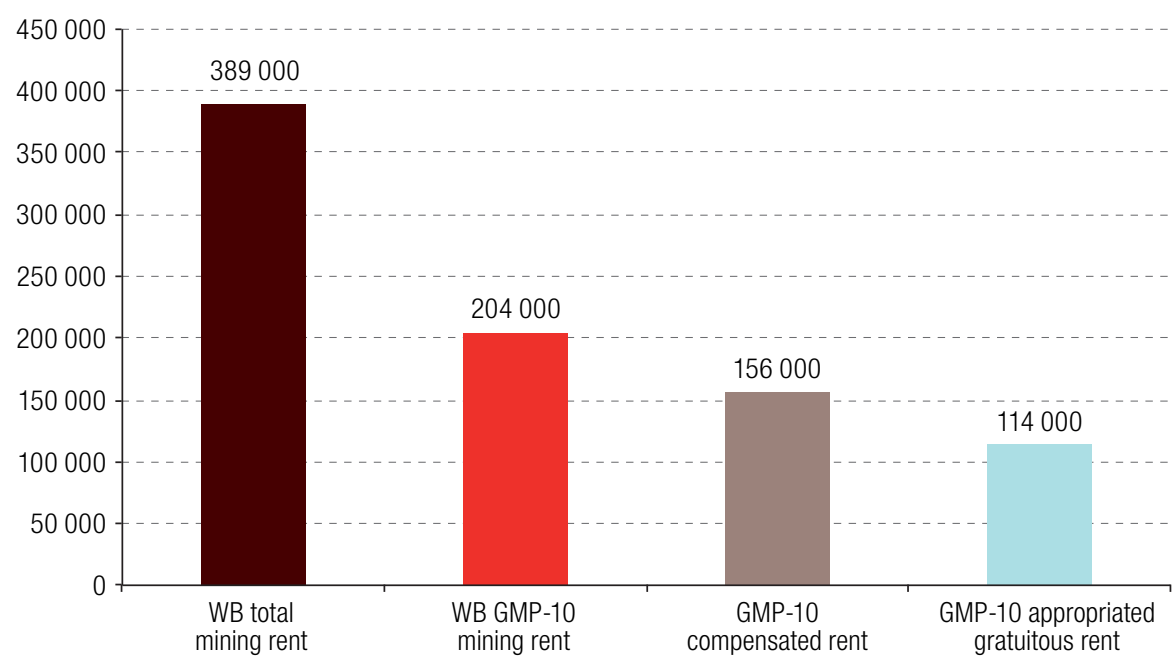

Source: Prepared by the authors.

a At October 2016 prices. 


\section{Sensitivity analysis}

As noted above, this study assumes a $2.5 \%$ probability of success in exploration, the lowest rate reported in the literature. It is also assumed that knowledge of the geology of the territory is non-existent. Chile is considered a mining location, which means that there is already a considerable knowledge of the geological characteristics of the country (SERNAGEOMIN, 2013). For this reason, recent studies have recommended a probability of $10 \%$ to $20 \%$, instead of $2.5 \%$ (Bartrop and Guj, 2009).

Moreover, based on a study by the Chilean Production Development Corporation (CORFO) (FCH/Alta Ley/CORFO, 2015), the direct unit costs of GMP-10 are assumed to be higher than those of CODELCO, averaging about US\$ 1.60 per pound in the period considered. However, the study by the Mining Benchmark international consultancy (Mining Press, 2013) indicates a unit cost of just US\$1.21 per pound in the period. This latter estimate is perhaps more credible than that of CORFO, considering the consensus of analysts and the fact that CODELCO's deposits are generally older and of lower grade than private-sector ones.

Although this study has focused on calculating a conservative and lower-bound estimate of economic rent, a sensitivity analysis was performed with more reasonable assumptions for the probability of exploration success and unit costs, based on the studies mentioned above. Table 1 reports GMP-10 appropriated gratuitous rents under different assumptions. The appropriated rent assuming a 10\% probability of success and the unit cost indicated by Mining Benchmark amounts to US\$163 billion, more than $30 \%$ above the base estimate of the present study. These simulations provide a quantitative idea of how conservative that estimation is.

Table 1

Chile: GMP-10 appropriated gratuitous rent in six scenarios, 2005-2014 (Billions of dollars)

\begin{tabular}{ccc}
\hline $\begin{array}{c}\text { Probability of exploration success } \\
\text { (percentages) }\end{array}$ & $\begin{array}{c}\text { Cost (CORF0) } \\
\text { (US\$ 1.60 per pound) }\end{array}$ & $\begin{array}{c}\text { Cost (Benchmark Mining) } \\
\text { (US\$ 1.21 per pound) }\end{array}$ \\
\hline 2.5 & 114 & 145 \\
\hline 5.0 & 126 & 157 \\
\hline 10.0 & 132 & 163 \\
\hline
\end{tabular}

Source: Prepared by the authors.

a At October 2016 prices.

\section{Selected comparisons}

This study has estimated that GMP-10 appropriated gratuitous rent totalling US\$ 114 billion in 2005-2014, representing an annual average flow equivalent to $5.1 \%$ of the country's GDP. The following examples put this in context.

The resources thus gifted averaged US\$11.4 billion per year between 2005 and 2014. It has been estimated that free education in the country, understood as full State funding at all levels of education, requires additional financing equivalent to almost US\$ 5 billion per year. It is also estimated that the recently enacted tax reform will raise US\$ 6 billion per year at most.

In other words, the wealth transferred annually to these large transnational companies in 2005-2014, could have financed free complete education, and the remaining US\$ 6.4 billion could have been used to definitively upgrade the health-care and pensions systems. All of this could have been done without the need to design and implement a complex tax reform with uncertain effects on investment and economic efficiency. 
Lastly, if Chile had saved these US\$114 billion and invested them as sovereign wealth funds, they would have generated a permanent annual income flow of over US\$ 7 billion, assuming a conservative investment pattern. In other words, the country would have a stable annual flow of income each year, irrespective of the fluctuations in the price of copper, equivalent to nearly all public health expenditure, which means that the country's public health services could be doubled permanently.

Lastly, Chile holds an annual telethon - a national solidarity activity to finance the care and rehabilitation of people with chronic or temporary disabilities, which raised roughly US\$47 million in its 2016 edition. The amount ceded gratuitously to the large-scale mining industry in 2005-2014, could finance about 2,420 telethons of that year.

\section{Final thoughts}

Perhaps the most relevant question that emerges from the estimates made here is: who gratuitously cedes these voluminous resources to these firms? The answer must clearly be sought among those in Chile's executive and legislative branches who allow the laws that make this absurd gift possible to persist. The political authorities of today's developed countries, such as Canada, the United States and Norway, changed their laws long ago to make a very large proportion of mining rents and natural resources taxable, which enabled them to stop squandering resources that belonged to all of their citizens and lay the foundations for strengthening their economies and social rights in their countries (Taylor and others, 2004; Guj, 2012; Figueroa, López and Gutiérrez, 2013; Bowie, 2016).

As far as the authors are aware, the fact that Chile is unable to recover these huge rents for all Chileans is also largely due to citizens' relative ignorance of the magnitude of the losses caused by unwillingness of the political and economic authorities to develop the necessary mechanisms to capture these rents. This study is intended to help correct this disinformation.

This article closes by recalling the comment by Minister of Finance, Rodrigo Valdés, quoted at the outset; but the question to be asked of "all Chileans" needs to be broader than what the Minister proposes. Instead of "how to use an additional peso" the question is why Chile does not keep the billions of dollars in rents gifted to private mining companies each year, which would finance many bridges, many schools, the wages of many thousands of public sector workers and pensions for many thousands of pensioners across the country. This should also be asked of the Presidents of the Republic and the parliamentarians of recent decades. Unless the people demand an answer, this huge amount of national wealth will continue to be squandered; and Chileans will continue to ignore President Balmaceda's clear warning, also quoted at the start of this article, of the risk of letting ".. this vast and wealthy region become nothing more than a foreign factory..." (Balmaceda, 1889).

\section{Bibliography}

Balmaceda, J. M. (1889), "Mensaje al Congreso", Santiago, 1 June.

Bartrop, S. and P. Guj (2009), "Estimating historical probabilities of discovery in mineral exploration", CET Quarterly News, No. 8, Crawley, Centre for Exploration Targeting, June.

Bowie, C. (2010), A Review of Mining Royalties in Australia, Brisbane, MinterEllison.

Brandt, N., P. Schreyer and V. Zipperer (2013), "Productivity measurement with natural capital", OECD Economics Department Working Papers, No. 1092, Paris, Organization for Economic Cooperation and Development (OECD). 
Budgetary Affairs Bureau (2015), "Evolución, administración e impacto fiscal de los ingresos del cobre en Chile", Santiago, Ministry of Finance [online] http://www.dipres.gob.cl/572/articles-133158_doc_pdf.

Castillo, R. (2015), El cobre: anatomía del mayor fraude minero en Chile, Santiago, Andros Impresores.

COCHILCO (Chilean Copper Commission) (2015), Anuario de estadísticas del cobre y otros minerales, 1996-2015, Santiago.

Correa, F. (2016), “¿Perdimos la oportunidad con el cobre?”, Working Paper, No. 1, Santiago.

El Mercurio (2017), "Alto Maipo y el riesgo de emprender", Santiago, 22 January [online] http://www. economiaynegocios.cl/noticias/noticias.asp?id=329285.

FCH/Alta Ley/CORFO (Fundación Chile/Alta Ley/Chilean Economic Development Agency) (2015), "Hoja de ruta de la minería 2035", Santiago [online] http://programaaltaley.cl/wp-content/uploads/2015/12/ Informe-Hoja-de-Ruta-2015.pdf.

Figueroa, E., R. E. López and P. Gutiérrez (2013), "Structural barriers to long-term productivity growth and sustainable development: lessons from the 'implicit industrial policy' imbedded in Chile's tax system", paper presented at the XXXI International Congress of the Latin American Studies Association, Washington, D.C.

Guj, P. (2012), Mineral Royalties and Other Mining-specific Taxes, Crawley, International Mining for Development Centre.

Hammes, J. K. (1985), "Economic rent considerations in international mineral development finance", Finance for the Minerals Industry, C. R. Tinsley and M. E. Emerson, Society for Mining Metallurgy.

Hodrick, R. J. and E. C. Prescott (1997), "Postwar U.S. business cycles: an empirical investigation", Journal of Money, Credit, and Banking, vol. 29, No. 1, Blackwell Publishing.

López, R. and E. Figueroa (2014), "Generación y distribución óptima de la renta económica en los sectores de recursos naturales en Chile", Santiago, Department of Economics, University of Chile.

Mining Press (2013), "Las grandes mineras de Chile celebran más leyes de cobre" [online] http://www. miningpress.com/nota/249996/grandes-mineras-celebran-avance-en-las-leyes-de-cobre.

Ministry of Finance (2015), Informe anual fondos soberanos, 2015, Santiago.

Poblete, N. (2015), "El cobre chileno y su renta futura", thesis, Santiago, University of Chile.

Ricardo, D. (2005), The Works and Correspondence of David Ricardo, P. Sraffa (ed.), Indianapolis, Liberty Fund.

SERNAGEOMIN (National Geology and Mining Service) (2013), "Concesiones mineras de exploración en Chile”, Santiago.

Shepherd, A. R. (1970), "Economic rent and the industry supply curve", Southern Economic Journal, vol. 37, No. 2, Wiley.

Taylor, A. and others (2004), When the Government is the Landlord, The Pembina Institute.

Tollison, R. D. (1982), "Rent seeking: a survey", Kyklos, vol. 35, No. 4, Wiley.

Valdés, R. (2016), "Valdés y reajuste de 7,5\% en sector público: 'está lejos de lo que Chile puede abordar'”, La Tercera, Santiago, 25 August [online] http://www.latercera.com/noticia/valdes-y-reajuste-de-75-ensector-publico-esta-lejos-de-lo-que-chile-puede-abordar/.

Wessel, R. (1967), "A note on economic rent", American Economic Review, vol. 57, No. 5, Nashville, Tennessee, American Economic Association.

World Bank (2016), "World Development Indicators" [online] www.worldbank.org. (2011), The Changing Wealth of Nations: Measuring Sustainable Development in the New Millennium, Washington, D.C. 


\section{Annex A1}

\section{Discounts in respect of copper concentrate sales}

Between 2005 and 2014, CODELCO sold an average of 14\% of its copper in concentrate form. When calculating sales revenue at market prices, the effect of this should be corrected for, as described below (COCHILCO, 2015):

(i) The amount of copper contained in the concentrate must be reduced to take account of two effects: humidity (10\% of the mass), and the cost of smelting and refining (15\% of the mass).

(ii) In addition, three costs must be deducted per ton of copper: US\$140 for maquila, US\$10 for the scale effect, and up to US\$ 400 for the losses associated with other minerals contained in the concentrate.

Given the above, the following are defined:

$q_{b}=$ gross amount of copper in the concentrate;

$q_{e}=$ effective amount copper in the concentrate, that is, after applying the two corrections described in point (i) above;

$q_{p}=$ loss or difference between the gross amount and the effective amount of copper, namely

$q_{p}=q_{b}-q_{e} ;$ and

$z=$ sum of the additional costs specified in point (ii) above, per effective ton of copper in the concentrate.

Thus, the rent associated with CODELCO can be expressed as a function of $\mathrm{c} 1$, the direct unit cost. This form is equivalent to that presented in equation (2) of this article. Details of the rent associated with CODELCO are presented, having corrected for copper in the form of concentrate (the other variables are those defined in section IV.2.b.).

$$
R_{b m, C o d}=p \cdot\left(q_{C o d}-q_{p}\right)+S_{C o d}-c_{1} \cdot q_{C o d}-z \cdot q_{e}(r+\delta) \cdot K_{C o d}
$$




\section{Annex A2}

\section{GMP-10 appropriated gratuitous rent}

Figure A2.1

Chile: GMP-10 appropriated gratuitous rent per year, as a proportion of GDP, 2005-2014 (Percentages)

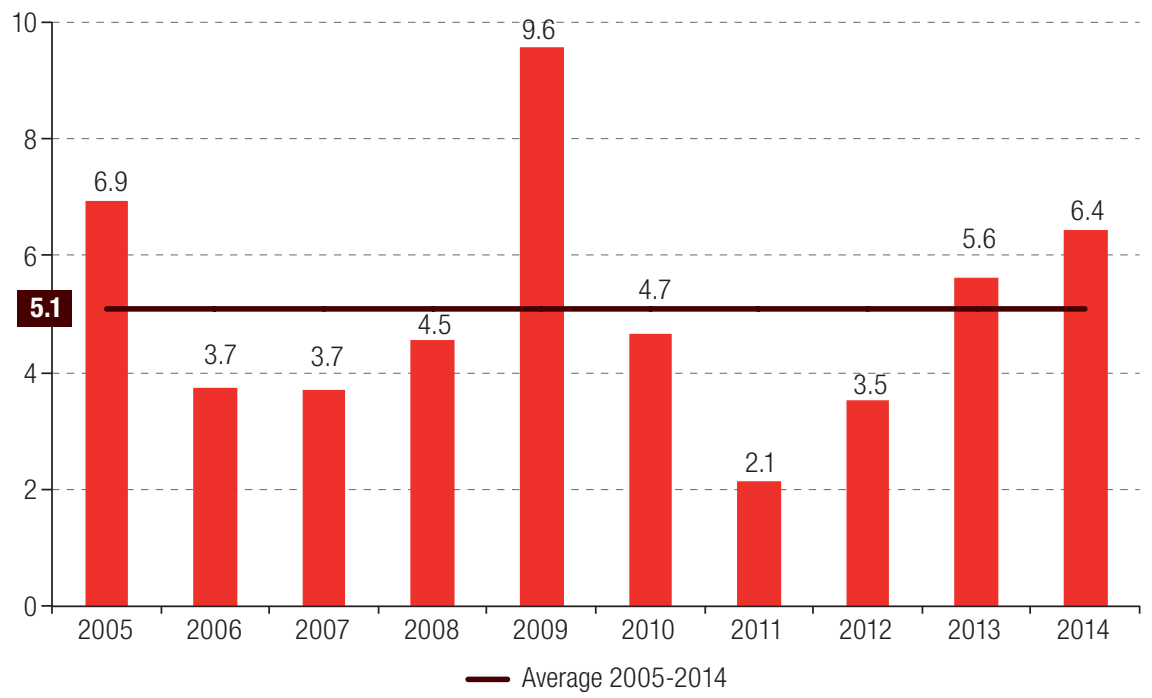

Source: Prepared by the authors.

Figure A2.2

Chile: GMP-10 appropriated gratuitous rent per year, as a percentage of public expenditure, 2005-2014

(Percentages)

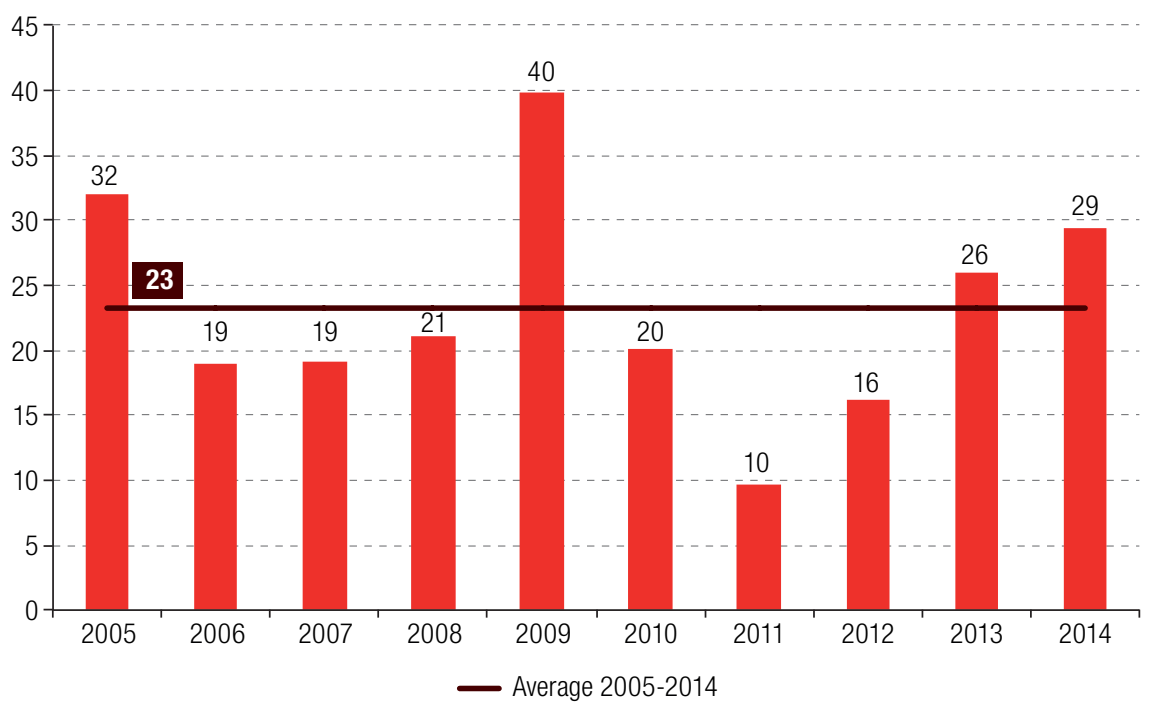

Source: Prepared by the authors. 


\section{Annex A3}

\section{Time path of four types of rent}

Figure A3.1 shows the annual estimates obtained for the four types of economic rent in the period spanning 2005 to 2014, measured in billions of dollars at October 2016 prices. The continuous grey line closest to the horizontal axis represents the GMP-10 appropriated gratuitous rent. This graph demonstrates that the estimation of this rent constitutes a "lower bound" estimate.

Figure A3.1

Chile: comparison of the four types of mining rent estimated in this study, 2005-2014

(Billions of dollars) $^{a}$

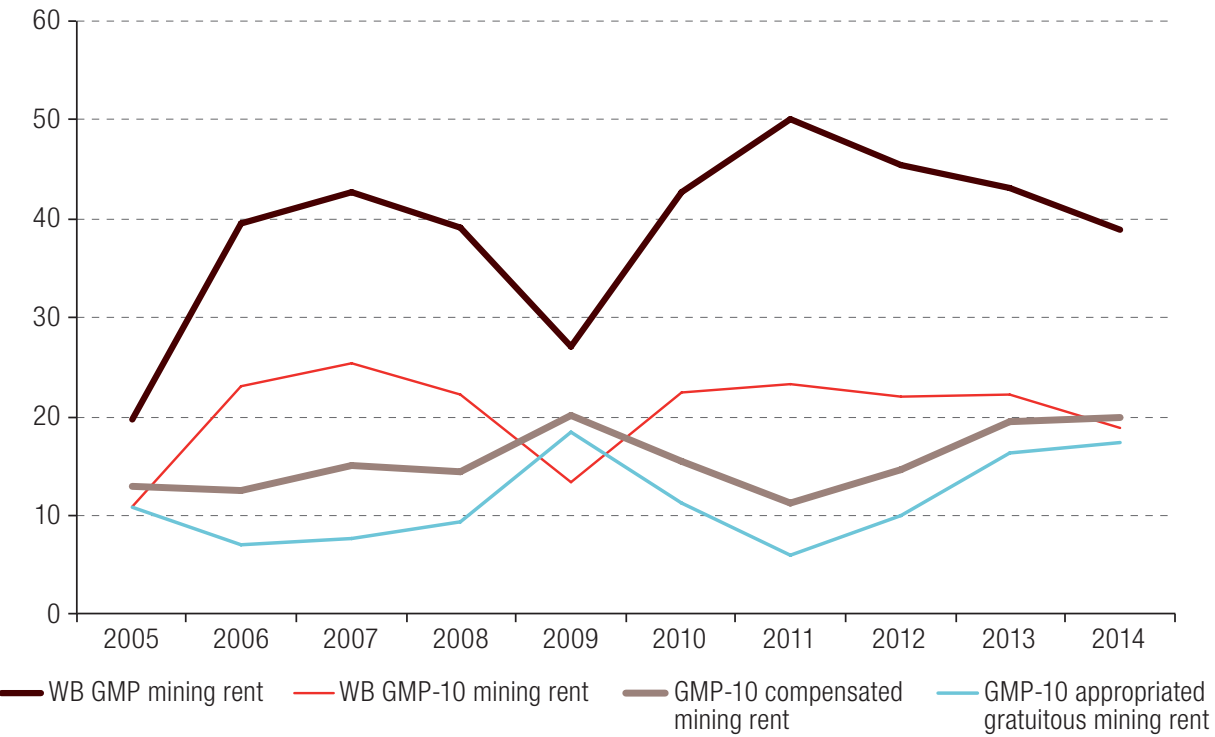

Source: Prepared by the authors.

a At October 2016 prices. 